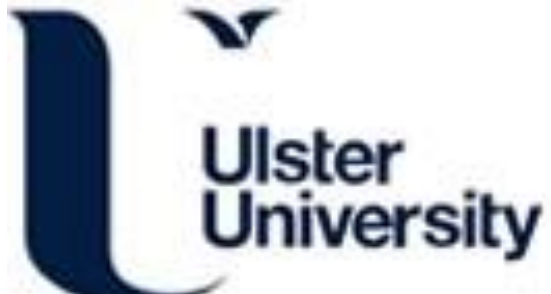

Media and Democracy in Turkey: Towards a Model of Neoliberal Media Autocracy

Akser, M., \& Baybars-Hawks, B. (2012). Media and Democracy in Turkey: Towards a Model of Neoliberal Media Autocracy. Middle East Journal of Culture and Communication, 5, 302-321. https://doi.org/10.1163/1873986500503011

Link to publication record in Ulster University Research Portal

\section{Published in:}

Middle East Journal of Culture and Communication

Publication Status:

Published (in print/issue): 01/11/2012

DOI:

10.1163/18739865-00503011

\section{Document Version}

Publisher's PDF, also known as Version of record

\section{General rights}

Copyright for the publications made accessible via Ulster University's Research Portal is retained by the author(s) and / or other copyright owners and it is a condition of accessing these publications that users recognise and abide by the legal requirements associated with these rights.

\section{Take down policy}

The Research Portal is Ulster University's institutional repository that provides access to Ulster's research outputs. Every effort has been made to ensure that content in the Research Portal does not infringe any person's rights, or applicable UK laws. If you discover content in the Research Portal that you believe breaches copyright or violates any law, please contact pure-support@ulster.ac.uk. 


\title{
Media and Democracy in Turkey: Toward a Model of Neoliberal Media Autocracy
}

\author{
Murat Akser ${ }^{\mathrm{a}}$ and Banu Baybars-Hawks ${ }^{\mathrm{b}}$ \\ a) Kadir Has University, Istanbul, Turkey \\ Email: makser@khas.edu.tr \\ b) Kadir Has University, Istanbul, Turkey \\ Email: banubhawks@khas.edu.tr
}

\begin{abstract}
This paper reveals the ways in which media autocracy operates on political, judicial, economic and discursive levels in post-2007 Turkish media. Newsmakers in Turkey currently experience five different systemic kinds of neoliberal government pressures to keep their voice down: conglomerate pressure, judicial suppression, online banishment, surveillance defamation and accreditation discrimination. The progression of restrictions on media freedom has increased in volume annually since 2007; this includes pressure on the Doğan Media Group, the YouTube ban, arrests of journalists in the Ergenekon trials, phone tapping/ taping of political figures and the exclusion of all unfriendly reporters from political circles. The levels and tools of this autocracy eventually lead to certain conclusions about the qualities of this media environment: it is a historically conservative, redistributive, panoptic and discriminatory media autocracy.
\end{abstract}

Keywords

media autocracy, censorship, surveillance, AKP, journalism

\section{Introduction}

Turkish media is under siege today by the ruling government of the AKP (Adalet ve Kalkınma Partisi/Justice and Development Party). The level of political pressure and legal restraints on news-reporting are visible in an unprecedented scale. Politics and the state have long influenced journalistic practices in Turkey and the mandate of media bosses, political and/or economic pressures have very often worked against the independence of journalists. However, the mainstream media in Turkey now operate under a new political economy of censorship in which big business and media conglomerates can only challenge the government and its repressive tactics toward the news media when their economic interests are threatened. 
At other times these media are silent and complacent. In contrast with the AKP's call for 'more democracy' in 2002 when it first came to power, the situation has become even worse, particularly after the AKP's second election victory in 2007. In this article we identify the key mechanisms used by the AKP government to suppress media critical of its policies. We argue that conglomerate pressure, judicial suppression, online banishment, surveillance defamation and finally accreditation discrimination are strategically used by the ruling government to suppress journalists in Turkey. We elaborate on these mechanisms further by looking into key developments in recent years.

There is a large body of literature on the right-wing takeover from independent publishers to conglomerates in the 1980s (see Bagdikian 2004; Skinner, Compton and Gasher 2005; McChesney 2008) and the field of political economy of the media is very much influenced by the debates by Chomsky and McChesney, who have introduced a variety of conceptual tools to the field (such as filtering, flac) (Hermann and Chomsky 2002; McChesney 2008). Throughout the 1990s during the conglomeration of newspapers and news channels a similar effect was also felt in Turkish media but on a different scale (see Kaya 1999; Adaklı 2001; Adaklı 2006; Kaya and Çakmur 2010). However, the current authoritarian transformation points toward a different direction in the formation of media in Turkey as there is an unprecedented increase in the use of executive and judiciary power against media criticism.

During long periods of modern Turkish history media freedoms were repressed by various right wing governments holding a parliamentary majority (Heper and Demirel 1996). Adapting the model proposed by Hafez (2005) to identify three types of phases in the democratization of press in developing countries, we can set an initial historical framework to identify the changing methods of media censorship in Turkey by consecutive governments. In the 'authoritarian phase' the political process is 'monopolized by an elite that rules not on the basis of democratic procedures and legitimacy but by coercion and force' (Hafez 2005: 146). This was the case in the Ottoman empire and in the early days of the Turkish republic when governments controlled the media through prior restraint (see Koloğlu 2004; Alemdar 2004). The authoritarian tone of the single party regime during this period (1923-1946) required press owners to act line with the republican discourse and aid the dissemination of the values of the new regime to the masses. This was followed by the 'transitory phase' (1947-1980), which can be further evaluated in two different periods due to the military intervention in 1960. The multi-party system began in 1946 in Turkey and the 
elections in 1950 brought the Democrat Party to power. The 1950s also correspond to the modernization of journalism in Turkey, in the sense that modern newspaper publishing technologies were introduced (Adaklı 2006). However, this period also carried with it the old habits of repression of the press and the media censorship imposed by the Democrat Party governments until the military intervention in 1960 . For a brief period in the 1960 legal safeguards were established to protect journalists from persecution by those in political power. The political transition that took place in Turkey at this time corresponds to what Hafez identifies as 'characterized by either reformist or revolutionary processes away from authoritarian regimes' (Hafez 2005: 147).

According to Hafez, in the third phase of the democratization of the press in developing countries, consolidation takes place. As he suggests, consolidation includes 'the establishment of institutions like a constitution, parliament, [and] democratic media as well as a stable political culture and vibrant civil society. Consolidation is prone to relapse because the authoritarian bureaucracy and societal values cannot be replaced from one day to another' (Hafez 2005: 147). We argue that the consolidation phase in Turkey corresponds to the period following the 1980 military intervention. During the 1980s, with the introduction of neoliberalism led by the Özal governments (see Önis 2004), the nature of journalism in Turkey became more sensationalist. Profit rather than journalistic ideals motivated newspapers as they changed hands. This process accelerated in the 1990s in the context of an economic transformation in media through convergence and concentration when big business groups acquired newspapers and TV stations to create media empires (Kaya 1994; Tuncel 1994; Sönmez 1996; Adaklı 2009; Sönmez 2010). Media alliances with the political elite during the $1990 \mathrm{~s}$ strengthened the economic power of the media, but also resulted in the establishment of various types of editorial censorship mechanisms and in the erosion of unions. Journalists were essentially stripped of their critical stance toward the government by media conglomerates that were protecting their economic interests (Finkel 2000; Tilic 2000; Tunç, 2003).

From 1999 when Turkey's EU membership candidacy was accepted until the launch of accession talks in 2005, Turkey leaped forward in democratizing its legislative framework for the media. However, this Europeanization of policy-making did not result in a paradigmatic change or transformation in the recognition of media freedoms but was rather limited to legislative adaptation (Sümer 2010). Nevertheless, even this legislative adaptation meant something for the supporters of the EU and when the AKP came to power in 2002, its government promised to pursue this democratization 
agenda and carry the country to its future in Europe. Thus, the AKP government's current negative approach to the media is very much in contradiction with its earlier promises. Following Hafez (2005), we can argue that Turkey had undergone the two stages mentioned above, inching away from the authoritarian model toward a more liberal and consolidated model until there appeared a fundamental debate between the press and the AKP government in Turkey. This last phase is proving to be difficult for both media conglomerates in Turkey and the ruling AKP government.

What we witness in Turkey today is the liberal right-wing media struggling to survive against the AKP-supported green media, some of which have recently been acquired by the new big business groups that originally represented small to medium-scale businesses in Anatolia in the 1990s and gradually expanded their businesses after the AKP came to power in 2002. ${ }^{1}$ This government sponsored transformation works in an autocratic manner, silencing media that are critical of the government. As the political rhetoric of the AKP government insists on calling the current administration 'the most liberal government of Turkey to date', the qualities of the media autocracy that the AKP administration has created resemble and can be compared to previous autocratic periods in Turkish political history. Yet never in the history of the media in Turkey were the redistribution of media power and the silencing of journalistic expression this paramount to political debate.

\section{The AKP Government and Media}

The formation of the AKP has its roots in the Islamic political movement created by Necmettin Erbakan in the late 1960 s. $^{2}$ Erbakan and the three political parties established were banned from politics after the military coups of 1971, 1980 and 1997. Only after the 1995 general elections did Erbakan and his followers have a chance to lead a government in a coalition. There was a younger generation of Islamists within Erbakan's party who were seen as moderate, pro-western, and in support of globalization and capitalism. This group, which later formed the original cadres of the AKP, became more visible after the so-called 'postmodern coup' that took

\footnotetext{
${ }^{1}$ For a further discussion on what 'green capital' indicates in the Turkish context, see Demir et al. 2004; Rubin 2005.

2 For understanding the rise of political Islam in Turkey, see Gülalp 1999; Gülalp 2003; Yavuz 1997 .
} 
place on 28 February 1997. On this date, the coalition government formed by the liberal right party DYP (Doğru Yol Partisi/True Path Party) and Islamic right party RP (Refah Partisi/Welfare Party) were given an ultimatum by the military. Then Prime Minister Necmettin Erbakan and his deputy Tansu Çiller were forced by the army to sign an edict, the purpose of which was to destroy the influence of Islamic political power. Shortly after the declaration of the edict, the government changed hands, Islamic high schools were closed, prominent members of the RP were arrested on disputed charges and eventually the RP was closed by the constitutional court and accused of trying to undermine the secular foundations of the republic. The mainstream media and their owners supported this soft coup and later it became common knowledge that the military were closely watching and sometimes interfering with print, broadcast and online media in the name of protecting the secular republic. ${ }^{3}$

The AKP was formed in 2001 in the midst of political strife that resulted in the closure of the FP (Fazilet Partisi/ Virtue Party) by the constitutional court. Its coming to power after the elections in November 2002 was a direct result of the organization and hard work of all the party members across the country, but there were other reasons behind the unprecedented public support it received, reasons that carried the party to power in three consecutive elections. ${ }^{4}$ Between 1991 and 2002 several coalition governments were accused of nepotism and corruption. Two consecutive economic crises in 2000 and 2001 had a crushing impact on most of the population. ${ }^{5}$ The mismanagement of the banking sector was influential in the emergence of both crises. The measures taken to regulate the banking sector also had an impact on the restructuring of the media sector, since some of these banks were owned by business groups also operating in the media. These groups' media assets were overtaken by the newly established Savings Deposit Insurance Fund (Tasarruf Mevduatı Sigorta Fonu, TMSF) and later acquired either by barons that already controlled a large portion of media or by new business groups entering the media sector. The AKP promoted its close business circles to benefit from this wave of restructuring and own media outlets on sale from 2005 onward.

\footnotetext{
${ }^{3}$ For more on the 28 February process and its repercussions on politics in Turkey, see Cizre and Çınar 2003.

4 There is a huge literature on the rise of the AKP to power and what this means for Turkish political history. For a selection, see Tepe 2005; Cinar 2006; Özbudun 2006; Önis 2006; Cizre 2008.

${ }^{5}$ For more on these two consecutive crises, see Önis and Rubin 2004.
} 
The first AKP period (2002-2007) saw the implementation of a solid economic program, the passing of reform packages in parliament to enter the EU, extensive privatization of state-owned economic enterprises and a proposed solution to the Cyprus problem. ${ }^{6}$ During this period the AKP government's policies were that of compliance with the media. The AKP government desperately tried to prove its conservative yet secular stance toward the military, the judiciary and intelligentsia in the mainstream media. The turning point for many came after several court cases related to the veiling ban were ruled upon-against the wishes of the AKP's voter base who wanted to study at universities and work in public offices with the Islamic headscarf. The second major controversy took place during the 2007 presidential election that resulted in the election of the former foreign minister of the government, Abdullah Gül, whose wife was wearing an Islamic headscarf. This crisis created the fear of another military coup and the media fueled this fear for the AKP establishment. The dust settled after the general elections that took place just a couple of months after the presidential election and the AKP had won a second time majority in parliament, declaring that the so-called apprenticeship phase was over and they were to enter the journeyman phase in politics. Prime Minister Erdoğan's election platform was a divisive one tending toward an 'us versus them' election pitch, warning all segments of society of a wrong choice and its possible aftermath. Media that are critical of Erdoğan and the AKP policies were also warned to behave. After the election, in his famous balcony speech, Prime Minister Erdoğan promised that all will be treated equal and the media need not fear. The facts proved otherwise (Güvenç 2007).

The AKP government's actions to reshape the media can be seen in the changes of media ownership patterns between 2002 and 2008 (Adaklı 2009). The media assets of two powerful groups, Ciner and Uzan, changed hands to more government friendly owners. Among these two, the rise and fall of the Uzan Group is remarkable in the sense that it perfectly reveals how the media scene has changed in Turkey in the last two decades. The Uzan family was known for its lavish lifestyle and together with very powerful media outlets they also owned the second largest GSM Company (TELSIM) in Turkey that was in business with the cell phone manufacturer Motorola. The family group benefited greatly from the privatization tenders in the 1990s. Most of the Uzan family were already being investigated

6 For more on the toots and changes of the AKP's political rhetoric, see Doğan 2005; Keyman 2010. 
by the previous governments for the mismanagement of their banks and not paying Motorola its share of billions of dollars of cellphones sold. Cem Uzan entered two consecutive elections is 2002 and 2007 and his party attracted an unprecedented voter turnout (around 7 percent of all of the popular vote). ${ }^{7}$ Uzan was critical of the AKP in the 2007 elections and targeted the prime minister in every public speech he made. Lawsuits followed after the election and Uzan family members fled the country and their companies were sized by the Savings Deposit Insurance Fund (TMSF). The media assets of the Uzan Group were sold to either international corporations, such as the Canadian company, CanWest, or to groups friendly to the government. The Uzan Group lost Star TV, Star Newspaper, Metro FM, Rock FM and Joy FM along with its national GSM operator license (Adaklı 2010: 591-595). The Doğan Group, which was on good terms with the AKP at that time, acquired Star TV and became the most powerful media conglomerate. We argue that the conglomerate pressure in the AKP media autocracy timeline began in 2007 with the ways in which the 'Uzan issue' was handled and later directed to the most powerful media conglomerate in Turkey: Aydın Doğan. This controversy is further assessed in the following section.

The year 2008 marks the beginning of waves of arrests of journalists in the Ergenekon investigation, which targeted some journalists, along with military and civilian bureaucracy who were allegedly involved in illegal activities to overthrow the government (Rainsford 2008; $B B C$ 2012). The arrests showed that the evidence was gathered through phone-tapping and Internet surveillance. The new technologies of surveillance that were revealed ranged from tapping into homes and offices through inactive cell phones to using laser technology to gather sound from inside the buildings. The arrests that started in 2008 continued in wave after wave. Police surveillance became so widespread that Prime Minister Erdoğan declared that even his phone was tapped (Hürriyet Daily News 2011d).

Next came Internet blackouts and bans in 2009. The opposition party and the NGOs opposed to the AKP widely used YouTube videos of AKP leaders to condemn their anti-secular discourse during the 2007 election campaigns. Fearing persecution through videos and facing another prosecution to close down the AKP at the constitutional court, the government used Information Technologies and Communication Authority (BTK)

\footnotetext{
${ }^{7}$ For more on the impact of Uzan family and Cem Uzan's political quest, see Bora 2002, Akın 2010.
} 
to regulate and block any website they found disturbing (Hürriyet 2007). The YouTube ban was not lifted until the AKP supported president-elect, Abdullah Gül, personally interfered in 2010. The year 2010 was important for the AKP as the government proposed many changes to the constitution. The main changes were made to the articles that allowed the control of the appointments of judges and prosecutors to higher courts. The constitutional referendum that took place on 12 September 2010 resulted in an AKP favored result.

After this major win in the 2010 constitutional referendum, Prime Minister Recep Tayyip Erdoğan convened a large gathering of all media representatives and to their shock declared a set of principles under which the media should operate in reporting news (Judson 2010). This approach sharply contrasted with his previous announcement, made after the general election in 2007, in which he indicated his empathy and understanding for those who did not vote for him and stated that he would be open to criticism of all kinds from all parties (Today's Zaman 2007). However, as of 2012, more than a hundred journalists have been arrested and are awaiting trial for allegedly trying to overthrow the government through violent means. These charges are based on phone tapping, unidentified witness accounts and some journal entries by military officials. Under these circumstances, it is no surprise that since 2007 there has been a consistent drop in Turkey's place in global human rights watch lists concerning freedom of the press. Freedom House Report on the Internet states that user rights are violated, users are blocked from reading and writing content and that there is 'substantial political censorship' (Freedom House 2011). Thomas Hammarberg, the Commissioner for Human Rights of the Council of Europe, also criticized Turkey on the very poor conditions regarding the freedom of press, indicating the increase in criminal proceedings and arrests involving journalists (Hammarberg 2011). The negative government practices toward news media of all forms point toward an increasingly strong neoliberal media autocracy in Turkey. Print and broadcast media reporters continually feel pressured toward self-censorship. Increasing number of veteran journalists such as Emin Çölaşan and Haluk Şahin either resigned or were dismissed from their positions due to pressures from the government (see Çölaşan 2007; Şahin 2011). The pressure used by the government to suppress the media can be compared to those of the neoliberal conservative governments of Berlusconi and Putin. Pressure on media bosses, the arrests of journalists, Internet bans, surveillance and taping (as well as defamation on YouTube) and accreditation blocking are also reported both in Italy and Russia. 


\author{
M. Akser and B. Baybars-Hawks / \\ 310 \\ Middle East Journal of Culture and Communication 5 (2012) 302-321
}

\title{
Conglomerate Pressure
}

The first problem we identified in relation to freedom of expression in the Turkish media is conglomerate pressure. The AKP government gives the impression of an administration that does not tolerate non-compliance with its policies and it requires the media to actively support the government. The government has legal tools that can be used indirectly through seemingly autonomous institutions such as the Savings Deposit Insurance Fund (TMSF), which was given legal authority to appropriate and resell the property and liquidity of businesses due to bankruptcy or criminal sentencing of the owner. The TMSF has been criticized for intervening in (i.e., politically manipulating) large business groups, as happened during the sales of the Uzan Group's media assets (see Aykol 2008). However, when they were unable to totally control large industry-owned media through legislative measures, the AKP government started using economic and politicaldiscursive tools. The most significant tool is conglomerate pressure, which takes the form of government imposed fines over taxes, previously overlooked by the government agencies. Although some of the economic measures taken against media conglomerates are entirely legal, it is problematic that they were imposed and enforced once these media companies became critical of the government. Political-discursive tools include government agenda setting, calling for boycotts of the press and 'sided' (biased) media arguments.

The AKP governments did not mind having conglomerates such as the Doğan Group (DYH) that praised its activities such as economic development and political stability. The two other large cross-media groups were Çukurova and Çalık; the latter is known for being close to the AKP cadres. Aydın Doğan, the owner of DYH, was a mid-level businessman until the late 1970 and the creation of his empire began with his acquisition of the two important newspapers in Turkey: Millyet in 1979 and Hürriyet in 1983. As of 2009, Doğan Media controlled more than 50 percent of all the print, audio-visual and new media in Turkey. Doğan is the owner of the daily newspapers Hürriyet and Radikal, and TV channels Kanal D and CNN Turk.

The controversy between Aydın Doğan and Recep Tayyip Erdoğan that took place in 2008 is a very significant case that reveals how economic and political-discursive tools are simultaneously used by the government. It began with the coverage of a court case taking place in Germany on the misuse of donations to Deniz Feneri (Lighthouse Foundation), an NGO in Germany. Aydın Doğan's newspapers started questioning the AKP 
governement's involvement in the fraud and whether the donations were used to fund the AKP's activities. Against these allegations, Prime Minister Erdoğan blamed Aydın Doğan for igniting this controversy, in retaliation for failing to acquire a government tender. The Doğan media group then claimed that they were under attack by the government for revealing the truth and his media outlets' news reporting were repressed through economic and political pressure (see Hürriyet 2008b). The government ministers and Prime Minister Erdoğan accused the Doğan Media Group of fraud and false news reporting, relying on the biased media line, and even made an open call to the supporters of his party to boycott Doğan Media newspapers; he claimed that these newspapers have a low number of readers anyway (Haber 24 2008). The government also used other discursive tools to control the media, the most common being the portrayal of Doğan Media and other similar groups as rich, snobbish, high class and bourgeoisie. The group's response to these tools has been to change its stance from gatekeeping to priming; that is, presenting a flood of negative portrayals of the government through all its media channels.

Our research from the onset was initiated by Aydın Doğan's defiant television call to Prime Minister Recep Tayyip Erdoğan, who denounced Aydın Doğan as biased, because Doğan's newspapers and television stations were increasingly critical of government policies. Aydın Doğan had fired prominent columnists and closed a critical newspaper (Gözcü) from his group to ease tensions with the government. This move failed to take the pressure off and he took a defiant position on television. The prime minister responded to these calls on television as well. The debate lasted for a few days on television and was then forgotten. Then Aydın Doğan was sued for billions of dollars in back tax payments. He tried to extricate himself from businesses that had dealings with the government, such as Turkish Oil Company. Ultimately, he could not even sell his media empire, as the government tax agency found irregularities in sales transfer payments from a German media company. Aydın Doğan resigned as CEO of his company, his chief journalist, Ertuğrul Özkök, left his post at the flagship newspaper Hürriyet. Currently, Doğan media has been cleared of all charges and Aydın Doğan has won in court cases relating to unpaid taxes. It is important to note that it is the exception, rather than the rule for a Turkish media mogul to take on the government for unfair treatment. Yet it has become quite common for a prime minister to attack the news media to gain popular support discursively by dubbing them 'richmen's pawns'. Once again, the media withdrew and made concessions to survive. 
Today, the Turkish government proactively sets the agenda by commenting on the liberal media. Unfortunately the scholarly writing on the issue of pressure on the media have counterparts in Vladimir Putin's Russia (Ognyanova 2009; Kiriya 2011) and Berlusconi's Italy (Ragnedda and Muschert 2011). Worse still, the censorship-related literature in the field only comes from Tonga, China and other non-democratic countries (Stockmann and Gallagher 2011, Vikilani 2010).

\section{Judicial Suppression}

Another problematic area is judicial suppression of journalists who are prosecuted for various statements they have made in print, Internet blogs and even phone conversations that were monitored (see Temelkuran 2012). Many people in Turkey believe that the arrests function to silence critics of AKP government and intimidate any potential critics (Temelkuran 2012). The waves of arrests that began in 2008 included prominent nationalist reporters Soner Yalçın (ODATV), Nedim Şener (Milliyet), Ergün Poyraz, Erol Manisalı (Cumhuriyet), Tuncay Özkan (Kanaltürk), and Mustafa Balbay (Cumhuriyet). The last two of these journalists were elected members of parliament in absentia in the 2011 general elections, but have not been released from prison; this adds yet another level of political and judicial complexity to an already contested issue. Another method of intimidation takes the form of police raids near dawn and searches of journalist's homes that result — at least at times - in no evidence on any criminal activity. One such notorious case included the arrest of a journalist, Ahmet Şık, because he had written (but not yet published) a book on the Islamization of bureaucracy (see Gottschlich 2011). Protests arose from many NGOs, who stated that the idea of a book that has not been made public in published form cannot be subject to criminal investigation because such action is unconstitutional and can be considered 'thought crime' (Reporters Without Borders 2011). The PDF version of the book became an instant hit and many journalists challenged the police to also arrest them on charges of having read the unpublished book. The book was eventually published with the satirical title: The Forbidden Book: Dare to Touch, It Burns You. In the case of the Ergenekon trials, dissenting journalists were arrested based on anonymous tips and some telephone conversations (see Hürriyet Daily News 2011a). They have been held pending trial since 2007 and have not been found guilty. While journalists cannot report or write critical reports against the government, the Islamic green media continually publishes reports of 
M. Akser and B. Baybars-Hawks /

Middle East Journal of Culture and Communication 5 (2012) 302-321

those arrested, labeling their colleagues 'criminal'. The number of journalists awaiting trial in prison had reached 94 as of March 2012 (Filkins 2012).

\section{Online Banishment}

The third area of analysis is the regulation of the Internet. Government regulatory bodies such as the Turkish Information and Communication Technology Authority applied bans on sites based on unfavorable comments about the government (Freedom House 2011). The blanket ruling of these agencies led to the banning of YouTube. YouTube could not be accessed by Turkish users until recently (Reuters 2010). The YouTube ban came into effect after the release of several videos related to anti-secular speeches made by several prominent AKP figures, including Prime Minister Tayyip Erdoğan and President Abdullah Gül. The ban was lifted several times by different courts but enacted by other district courts. People found ways of bypassing the ban using proxy sites and the prime minister even declared that he could access YouTube. The ban was lifted close to the general elections of June 2011. Yet the government silently introduced a blanket filter in August 2011 that affected every Internet user in Turkey (Today's Zaman 2011a). The aim of the government, as it was argued, was to protect young children from sex, drugs, and violence on the Internet. The protesters interpreted the move as anti-democratic, because it would operate as a blanket ban covering everyone without their consent. Due to protests on the ban, the government took a step back and made filtering voluntary. Today there are thousands of sites that can be seen from the rest of the world but not from Turkey, because government agencies block them (Hürriyet Daily News 2011c).

Another example of online intimidation is the case of Ekşi Sözlük (The sour times), a satirical website where users mock people and events by adding entries. The site was blocked by court order for mocking Islamic figures close to the AKP government (Today's Zaman 2011c). The entries were removed and the site was allowed to operate shortly after. Another scandal arose when the anonymous users of the site suddenly discovered that they are being sued by various people they mocked (Eğrikavuk 2011); it seems that the government required the managers of the website to reveal the true identities of individuals who had trusted the use of aliases and freely criticized the government (Jones 2011; Karaca 2011; Kelly 2011). The loss of anonymity and fear of persecution is undermining Internet freedom in Turkey today. 


\section{Surveillance Defamation}

Given many examples of private video and audio recordings in the hands of political rivals it can be argued that there is increased circulation of private information in the hands of the police, prosecutors, and also journalists who support government policies. Access to private information at this level suggests the existence of a big brother like surveillance group within the police that serves the interests of the government by spying on potential critics of the government. Suspected but unproven, this group seems to be able to provide defamatory surveillance videos of prominent figures, military and civilian bureaucracy, and members of parliament, especially those in opposition, to use them for leverage and to create a sense of guilt by association (Kayakiran 2009). The complacent attitude of the government in not blocking these videos on the Internet is in fact a passive way of aiding surveillance defamation. During the summer of 2011, general elections tapes popped up on the Internet featuring footage of sexual relations by opposition members of parliament. Just days before the general elections six prominent members of MHP resigned after the release of surveillance videos of their private lives (Hürriyet 2011a). It was common to use terms that include moral tones such as 'adulterer caught in love nest' by the government-friendly media (Fraser 2011; Strauss 2011). Even the then leader of the main opposition party CHP resigned due to such defamatory tape recordings released on YouTube. The opposition parties called for a ban on the videos, yet the government did not respond (Jenkins 2011). Even judges and prosecutors made the news as they installed jammers in their offices to prevent possible surveillance (Hürriyet 2009).

\section{Accreditation Discrimination}

Finally the new accreditation regime came into place. Certain journalists and news reporters are excluded from reporting the news from government authorities. The 'safe' press list released by prime minister's press bureau includes journalists deemed safe and friendly; they are given direct access to the prime minister and government officials. The creation of the accreditation regime reflects the biased-media discourse of Prime Minister Tayyip Erdoğan. In Erdoğan's view, there is friendly media and there is sided media. Erdoğan also used the biased media argument during his election campaign in 2007. In November 2008 several journalists from all parts of the political spectrum (but not siding with the AKP) were denied access to 
report on the government. This ban attracted international criticism as the WAN (World Association of Newspapers) and ENPA (European Newspaper Publishers Association) wrote an open letter to Tayyip Erdoğan requesting the lifting of the ban (Hürriyet 2008c). Hence we argue that by attempting to control who can report on it, the AKP government has created another tool for controlling the media.

The practice of gathering media barons and dictating to them what not to report has been a common practice by AKP officials. After a third majority win in 2011, it is known to the general public that Erdoğan has dropped all lawsuits against journalists who criticized him during the election (Today's Zaman 2012). Yet periodic meetings are held by the prime minister and his deputies with media barons about what to publish or broadcast (Hürriyet 2011b). The exclusion of news editors from the meetings indicates that the AKP government views the news media as a politically engaged economic enterprise rather than a public service that functions to check and balance political authority in a liberal democracy.

\section{Conclusion}

In this article we have identified measures used by the AKP government to control critical media. As we suggested, the media autocracy in Turkey today can be categorized under five headings: conglomerate pressure, judicial suppression, online banishment, surveillance defamation and accreditation discrimination.

Conglomerate pressure is exercised as an autocratic tool to control media barons. It includes scare tactics, such as prosecution for unpaid back taxes and the imposition of fines on media conglomerates that may result in financial disaster for media moguls, as in the Aydın Doğan case in 2008. Media barons may have to replace newspaper management or tone down their critical tone to stay in business.

Judicial suppression is a way creating fear that government officials and MPs will continually bring lawsuits against journalists for criticizing the government. This includes special prosecutors arresting journalists without producing evidence and the creation of sided/biased media discourse by the prime minister. The Ergenekon trials and the journalists - arrested and still awaiting trail for alleged terrorist ties-have the common denominator of being critical and anti-globalization in their stance.

Online banishment is used to block websites that have damaging evidence or critical material against the government. The blocked sites include 


\section{Akser and B. Baybars-Hawks /

YouTube and other popular sites such as Ekşi Sözlük. The registered and anonymous users of such sites are found, sued and fined. Online banishment includes the closing down of websites that criticize the government, the creation of exclusion lists by the Telecommunications Authority so that users cannot access certain sites, the creation of a filtering system based on moral codes (blanket control), the YouTube ban, the loss of anonymity of users (Ekşi Sözlük) and regulatory decisions based on moral codes. The government backs down from the bans from time to time to avoid userprotests, yet the wide range of blocked content increases daily.

Surveillance defamation involves arrests based on phone tapping, Internet surveillance of journalists and dissenters, general voice surveillance and special mobile surveillance vehicles employed to follow dissenters. The unknown groups distribute damaging videos of the AKP's political opponents. The complicity of the AKP government is evident in their refusal to block or ban such videos, making this, in effect, a passive tactic to shut down criticism. The change in the opposition party CHP's and MHP's leadership during 2011 came as a result of the spread of such videos on YouTube.

Accreditation discrimination is a direct outcome of the new accreditation regime, in which journalists critical of the government are forbidden access to government information and interviews with ruling politicians. This move in 2008 was criticized widely at home and abroad, yet is still in practice today.

The media in Turkey has long been under economic and political restraints. Journalists have shown reactionary and sometimes partisan attitudes toward governments. Yet until recently there was a glimmer of hope of practicing the informative and critical function of journalism. In contemporary Turkey, even the basic operation of journalism cannot be properly performed due to fear, intimidation, bans, imprisonments, blocked access to information and defamatory surveillance. The media autocracy of today can only usher in a second-rate and a lesser democracy in Turkey.

\section{References}

Adakll, Gülseren (2001). Yayıncllık Alanında Mulkiyet ve Kontrol [Ownership in the broadcasting sector and its regulation]. In Beybin Kejanlıoğlu, S. Celenk and Gülseren Adaklı (eds.), Medya Politikaları, pp. 145-204. Ankara: Imge.

—_(2006). Türkiye’ de Medya Endüstrisi: Neoliberalizm Çağında Mülkiyet ve Kontrol İlişkileri [Media industry in Turkey: Ownership and control in the age of neoliberalism]. Ankara: Ütopya. 
- (2009). The Process of Neoliberalisation and the Transformation of the Turkish Media Sector in the Context of the New Media Architecture. In Jackie Harrison and Bridgette Wessel (eds.), Mediating Europe: Communication in Contemporary European Culture Contents, pp. 286-317. Oxford: Berghahn.

- (2010). 2002-2008: Türk Medyasında AKP Etkisi. In İlhan Uzgel, and Bülent Duru (eds.), AKP Kitabl: Bir Dönüşümün, pp. 559-613. Istanbul: Phoenix.

Akın, Altug (2010). Dirty Seeds of Media Transformation in Turkey: The Vertigo of Communication. EastBound 2010(2). Accessed 9 August 2012: http://eastbound .eu/2010/akin.

Alemdar, Korkmaz (2004). The Early Years of the Republican Press. BoğaziçiJournal 18(1-2): 35-41.

Aykol, Hüseyin (2008). Haber Basinindan Islamci Medyaya. Istanbul: Agora Kitaplığı.

Bagdikian, Ben H. (2004). The New Media Monopoly. Boston: Beacon Press.

BBC (2012). Turkey's Military and the Alleged Coup Plots. Accessed 11 March 2012: http:// www.bbc.co.uk/news/world-europe-16447625, 6 January 2012.

Bora, Tanıl (2002). Cem Uzan ve Neo-Fasizmin Yeni Yuzu: Sirket Konserlerinden Partiye. Birikim 162: 53-6o.

Chomsky, Noam (2003). Media Control. New York: Seven Stories Press.

Cinar, Menderes (2006). Turkey's Transformation Under the AKP Rule. Muslim World 96: $469-486$.

Cizre, Ümit (2008). Secular and Islamic Politics in Turkey: The Making of the Justice and Development Party. London and New York: Routledge.

Cizre, Ümit and Menderes Çınar (2003). Turkey 2002: Kemalism, Islamism, and Politics in the Light of the February 28 Process. South Atlantic Quarterly 102(2-3):309-332.

Çölaşan, Emin (2007). Kovulduk Ey Halkin Unutma Bizi. Ankara: Bilgi.

Demir, Ömer, Mustafa Acar and Metin Toprak (2004). Anatolian Tigers or Islamic Capital: Prospects and Challenges. Middle Eastern Studies 40(6): 166-188.

Doğan, E. (2005). The Historical and Discoursive Roots of the Justice and Development Party's EU Stance. Turkish Studies 6(3): 421-437.

Eğrikavuk, Işıl (2011). 'Ekşi-users' Raid Sour Web Freedom. Hürriyet Daily News. Accessed 22 April 2012: http://www.hurriyetdailynews.com/default.aspx?pageid $=438 \& \mathrm{n}=8216 \mathrm{eksi}$ -users8217-raids-sour-web-freedom-2011-06-26, 6 June 2011.

Elgar, Katrin, Daniel Steinvorth and Issabel Hülsen (2009). Political Feud in Turkey Scares Off Foreign Investors. Der Spiegel. Accessed 20 April 2012: http://www.spiegel.de/ international/world/0,1518,615422,oo.html, 25 March 2009.

Filkins, Dexter (2012). Turkey's Jailed Journalists. New Yorker. Accessed 9 August 2012: http:// www.newyorker.com/online/blogs/comment/2012/o3/turkeys-jailed-journalists.html, 9 March 2012.

Finkel, Andrew (2000). Who Guards the Turkish Press? A Perspective on Press Corruption in Turkey. Journal of International Affairs 54(1): 147-166.

Fraser, Susan (2011). Turkish Website Threatens to Post More Sex Tapes. Guardian. Accessed 22 April 2012: http://www.guardian.co.uk/world/feedarticle/9651433, 18 May 2011.

Freedom House (2011). Accessed 17 July 2011: http://www.freedomhouse.org/report/freedom -world/2011/turkey.

Friedman, Steven (2011). Whose Freedom? South Africa's Press, Middle-class Bias and the Threat of Control. Ecquid Novi: African Journalism Studies 32(2):106-121.

Gottschlich, Jürgen (2011). Arrested Journalist's Book Claims Turkish Police Infiltrated by Islamic Movement. Der Spiegel. Accessed 19 April 2012: http://www.spiegel.de/ international/world/o,1518,755508,oo.html, 6 April 2011. 
Gülalp, Haldun (1999). Political Islam in Turkey: The Rise and Fall of the Refah Party. Muslim World 89: 22-41.

_ (2003). Globalization and Political Islam: The Social Bases of Turkey's Welfare Party. International Journal of Middle Eastern Studies 33: 433-448.

Güvenç, Duygu (2007).The AKP Celebrates Glorious Victory. Turkish Daily News. 23 July 2007.

Haber 24 (2008). Erdoğan: Doğan gazetelerini almayın. Accessed 11 March 2012: http://www .haber-24.com/28793_Erdogan-Dogan-Gazetelerini-Almayin.htm, 19 June 2008.

Hafez, Kai (2005). Globalization, Regionalization and Democratization: The Interaction of Three Paradigms in the Field of Mass Communication. In Robert A. Hackett and Yuezhi Zhao (eds.), Democratizing Global Media: One World, Many Struggles, pp. 145-164. Lanham, MD: Rowman and Littlefield.

Hammarberg, Thomas (2011). Freedom of Expression and Media Freedom in Turkey. 12 July 2011, Report of the Commissioner for Human Rights of the Council of Europe, Strasbourg.

Heper, Metin and Tanel Demirel (1996). The Press and the Consolidation of Democracy in Turkey. Middle Eastern Studies 32(2): 109-123.

Herman, Edward S. and Noam Chomsky (2002). Manufacturing Consent: The Political Economy of Mass Media. New York: Pantheon.

Herman, Edward and Robert McChesney (1999). The Global Media in the Late 1990s. In Hugh Mckay (ed.), The Media Reader: Continuity and Transformation, pp. 178-210. London: Sage.

Hürriyet (2007). YouTube tartışması. Accessed 11 March 2012: http://hurarsiv.hurriyet.com.tr/ goster/ShowNew.aspx?id=6082796, 8 March 2007.

Hürriyet (2008a). Demokrasi ve özgür basını içine sindir. Accessed 11 March 2012: http:// hurarsiv.hurriyet.com.tr/goster/ShowNew.aspx?id=9843271, 8 September 2008.

Hürriyet (2008b). Turkish PM' s Attack on Media Casts Shadow on Supervisory Bodies. Accessed 11 March 2012: http://hurarsiv.hurriyet.com.tr/goster/haber.aspx?id=9888517 \&tarih=2008-09-13, 9 September 2008.

Hürriyet (2008c). Gazetecilerin Akreditasyonu Geri Verilsin. Accessed 11 March 2012: http://hurarsiv.hurriyet.com.tr/goster/ShowNew.aspx?id=10592664, 18 December 2008.

Hürriyet (2009). Mahkemede Bile Dinlenme Korkusu. Accessed 11 March 2012: http:// hurarsiv.hurriyet.com.tr/goster/ShowNew.aspx?id=11224134, 17 March 2009.

Hürriyet (2011a). 1 Kaset 6 İstifa" (1 Tape 6 Resignations). Accessed 11 March 2012: http:// hurarsiv.hurriyet.com.tr/goster/ShowNew.aspx?id=17845464, 21 May 2011.

Hürriyet (2011b). Arınç, medya patronlarıyla bir araya geldi. Accessed 11 March 2012: http://hurarsiv.hurriyet.com.tr/goster/ShowNew.aspx?id=19293913, $21 \quad$ November 2011.

Hürriyet Daily News (2011a). Turkish Police Raid Printing House, Erase Unpublished Book. Accessed 11 March 2012: http://www.hurriyetdailynews.com/default.aspx?pageid $=438 \& \mathrm{n}=$ turkish-police-raids-printing-house-erases-unpublished-book-2011-03-24, 24 March 2011.

Hürriyet Daily News (2011b). Turkish Internet Filtering Plan 'Unconstitutional' Experts Say. Accessed 19 April 2012: http://www.hurriyetdailynews.com/default.aspx?pageid $=438 \& \mathrm{n}=$ internet-filter-2011-05-04, 5 May 2011.

Hürriyet Daily News (2011c). Action against Turkey's Internet Ban Demanded in Europe. Accessed 11 March 2012: http://www.hurriyetdailynews.com/default.aspx?pageid $=438 \& \mathrm{n}=$ member-of-the-european-parliament-asks-european-commission-to-take -action-against-the-internet-ban-in-turkey-2011-05-24, 24 May 2011. 
Hürriyet Daily News (2011d). Erdoğan' s Bedroom Talks Illegally Taped: Minister. Accessed 11 March 2012: http://www.hurriyetdailynews.com/erdogans-bedroom-talks-illegally -taped-minister.aspx?pageID $=238 \& \mathrm{nID}=8277 \&$ NewsCatID $=338$, 1 December 2011.

Jenkins, Gareth H. (2011). Above the Threshold, Below the Belt: The Video Campaign against the MHP. Turkey Analyst 4(11). Accessed 1 March 2012: http://www.silkroadstudies.org/ new/inside/turkey/2011/110530A.html.

Jones, Dorian (2011). Critics Challenge New Internet Controls in Turkey. Voice of America. Accessed 22 April 2012: http://www.voanews.com/english/news/europe/Critics -Challenge-New-Internet-Controls-in-Turkey-120641439.html, 25 April 2011.

Judson, D. (2010). Erdoğan Seeks to Turn 'New Page' with Turkey's News Media. Hürriyet Daily News. Accessed 11 January 2011: http://212.31.2.101/n.php?n=Erdoğan-seeks-to -turn-new-page-with-turkeys-news-media-2010-09-25, 25 September 2010.

Karaca, Ekin (2011). State's 'Secure' Internet Filter Applied on 22 November. Bianet: News in English. Accessed 22 April 2012: http://bianet.org/english/english/134200-states -secure-internet-filter-applied-on-22-november, 22 November 2011.

Kaya, Raşit (1994). A Fait Accompli: Transformation of Media Structures in Turkey. Metu Studies in Development 21(3): 383-404.

(1999). Türkiye'de 1980 Sonrası Medyanın Gelişimi ve İdeoloji Gereksinimi. Türk-İş Yillı̆̆ı' 99, 2 Cilt. Ankara. Accessed 19 April 2012: http://www.dorduncukuvvetmedya .com/arsiv/akaya.htm.

Kaya, Raşit and Barış Çakmur (2010). Politics and the Mass Media in Turkey. Turkish Studies $11(4): 521-537$.

Kayakiran, Firat (2009). Surveillance Spooks Turks as Wiretaps Grow. Hürriyet Daily News. Accessed 22 April 2012: http://www.hurriyet.com.tr/english/domestic/11335022.asp, 31 March 2009.

Kelly, Spencer (2011). Internet Censorship Increases in Turkey. BBC News. Accessed 22 April 2012: http://news.bbc.co.uk/2/hi/programmes/click_online/9647872.stm, 25 November 2011.

Keyman, E. Fuat (2010). Modernization, Globalization and Democratization in Turkey: The AKP Experience and its Limits. Constellations 17: 312-327.

Kiriya, Iliya and Anna Kachkaeva (2011). Economical Forms of State Pressure in Russian Regional Media. Romanian Journal of Journalism and Communication 6(2): 5-11.

Koloğlu, Orhan (2004). The Printing Press and Journalism in the Ottoman State. Boğaziçi Journal $18(1-2): 27-33$.

McChesney, Robert (2008). The Political Economy of Media: Enduring Issues, Emerging Dilemmas. New York: Monthly Review Press.

Meyen, Michael and Anke Fiedler (2011). Media Control in the GDR as Political PR Operation. A Case Study on Structures of Public Communication in Socialist Countries. Journal of Media Research 4(1): 3-12.

Oates, Sarah (2007). The Neo-Soviet Model of the Media. Europe-Asia Studies 59(8): 1279-1297.

Ognyanova, Katherine (2009). Careful What You Say: Media Control in Putin's RussiaImplications for Online Content, Conference Papers-International Communication Association, 2009 Annual Meeting.

Öncü, Ayşe (2004). The Interaction of Markets and Politics: The Remaking of the Turkish Media Industry in the 199os. BoğaziçiJournal 18(1-2): 11-26.

Önis, Ziya (2004). Turgut Özal and his Economic Legacy: Turkish Neo-Liberalism in Critical Perspective. Middle Eastern Studies 40(4): 113-134.

_ (2006). Globalization and Party Transformation: Turkey's Justice and Development Party in Perspective. In Peter Burnell (ed.), Globalizing Democracy: Party Politics in 
Emerging Democracies, pp. 122-140. London: Routledge,Warwick Studies on Globalization.

Önis, Ziya and Barry Rubin (eds.) (2004). The Turkish Economy in Crisis. London: Frank Cass.

Özbudun, Ergun (2006). From Political Islam to Conservative Democracy: The Case of the Justice and Development Party in Turkey. South European Society and Politics 11(3-4): $543-557$.

Ragnedda, Massimo and W. Glenn Muschert (2011). The Political Use of Fear and News Reporting in Italy: The Case of Berlusconi's Media Control. Journal of Communications Research 2(1): 43-54.

Rainsford, Sarah (2008). 'Deep State' Plot Grips Turkey. BBC News. Accessed 22 April 2012: http://news.bbc.co.uk/2/hi/europe/7225889.stm, 4 February 2008.

Reporters Without Borders (2011). Seizure and Destruction of Ahmet Sik's Unpublished Book: A Very Dangerous Precedent. Accessed 14 February 2012: http://en.rsf.org/ turquie-seizure-and-destruction-of-ahmet-25-03-2011,3989o.html, 25 March 2011.

Reuters (2010). Turkey Reinstates YouTube Ban. Accessed 19 April 2012: http://www.reuters .com/article/2010/11/03/us-turkey-youtube-idUSTRE6A227C20101103, 3 November 2010.

Rubin, Michael (2005). Green Money, Islamist Politics in Turkey. Middle East Quarterly 12(1): $13-23$.

Şahin, Haluk (2011). Can Cekisen Bir Meslek Uzerine Son Notlar [Final notes on a dying profession]. Istanbul: Say.

Skinner, David, James Compton and Mike Gasher (2005). Converging Media, Diverging Politics: Political Economy of News in the United States and Canada. Lanham, MD: Lexington Books.

Sönmez, Mustafa. (1996). Türk Medya Sektöründe Yoğunlaşma ve Sonuçları. Birikim 92: $76-87$.

— (2010). Medya, Kültür, Para ve İstanbul İktidarı. Istanbul: Yordam.

Sümer, Burcu (2010). The Impact of Europeanisation on Policy-making in Turkey: Controversies, Uncertainities and Misfits in Broadcasting Policy (1999-2009). Ankara Üniversitesi Avrupa Toplulukları Araştırma ve Uygulama Merkezi Araştırma Dizisi, No. 35. Ankara: ATAUM.

Stockmann, Daniela and Mary E. Gallagher (2011). Remote Control: How the Media Sustain Authoritarian Rule in China. Comparative Political Studies 44(4): 436-467.

Strauss, Delphine (2011). Sex Tapes Cast Cloud over Turkey Elections. Financial Times. Accessed 9 August 2012: http://www.ft.com/cms/s/o/1463a932-84af-11eo-afcb -00144feabdco.html\#axzz1snPmhpsl, 22 May 2011.

Temelkuran, Ece (2012). Turkish Journalists are Very Frightened-But We Must Fight this Intimidation. Guardian. Accessed 14 February 2012: http://www.guardian.co.uk/ commentisfree/2012/jan/27/turkish-journalists-fight-intimidation, 27 January 2012.

Tepe, Sultan (2005). Turkey's AKP: A Model 'Muslim-Democratic' Party?Journal of Democracy 16(3): 69-82.

Tilic, Dogan (200o). Media Ownership Structure in Turkey. Ankara: Progressive Journalists Association.

Today's Zaman (2007). Erdoğan Turns New Page in Second Term in Power. Accessed 11 January 2012: http://www.todayszaman.com/news-117494-Erdoğan-turns-new-page -in-second-term-in-power.html, 24 July 2007.

Today's Zaman (2011a). Filter Options not a Threat to Internet Freedoms, says BTK. Accessed 19 April 2012: http://www.todayszaman.com/news-242950-filter-options-not-a-threat -to-internet-freedoms-says-btk.html, 5 May 2011. 


\section{Akser and B. Baybars-Hawks /}

Today's Zaman (2011b). Ekşi Sözlük Officials Respond to Claims of Defamation of Character. Accessed 9 August 2012: http://www.sundayszaman.com/sunday/newsDetail getNewsById.action?newsId=263504, 21 November 2011.

Today's Zaman (2011c). Turkish Court Accepts Online Blasphemy Case, ECtHR Ruling Precedent. Accessed 19 April 2012: http://www.todayszaman.com/news-266864 -turkish-court-accepts-online-blasphemy-case-ecthr-ruling-precedent.html, $\quad 27$ December 2011.

Today's Zaman (2012). Court Drops Charges against Turkish Journalist after Erdoğan Withdraws Case. Accessed 19 April 2012: http://www.todayszaman.com/newsDetail getNewsById.action?load=detay\&newsId=275125\&link=275125, 22 March 2012.

Tuncel, Hakan (1994). Bab-Ali'den İkitelli'ye. Birikim 64: 33-38.

Tunç, Aslı (2003). Faustian Acts in Turkish Style: Structural Change in National Newspapers as an Obstacle to Quality Journalism in 1990-2003. In Orlin Spassov (ed.), Quality Press in Southeast Europe, pp. 306-323. Sofia, Bulgaria: SOEMZ/Sofia University.

Vela, Justin (2012). Behind Bars in the Deep State. Foreign Policy. Accessed 12 January 2012: http://www.foreignpolicy.com/articles/2012/01/11/behind_bars_in_the_deep _state?page $=0,2,11$ January 2012.

Vikilani, Sione F. (2010). Media Freedom and State Control in Tonga. Pacific Journalism Review 16(2): 62-80.

Yavuz, M. Hakan (1997). Political Islam and the Welfare (Refah) Party in Turkey. Comparative Politics 30(1): 63-82. 